\title{
BMJ Open Factors associated with possession of accurate knowledge regarding occupational health management among operations leaders of radiation decontamination workers in Fukushima, Japan: a cross-sectional study
}

\author{
T Hidaka, ${ }^{\odot}$ T Kakamu, ${ }^{\odot}$ S Endo, H Kasuga, Y Masuishi, T Kumagai, S Sato, \\ T Sasaki, T Fukushima
}

To cite: Hidaka T, Kakamu T, Endo S, et al. Factors associated with possession of accurate knowledge regarding occupational health management among operations leaders of radiation decontamination workers in Fukushima, Japan: a crosssectional study. BMJ Open 2019:9:e025729. doi:10.1136/ bmjopen-2018-025729

- Prepublication history and additional material for this paper are available online. To view, please visit the journal (http:// dx.doi.org/10.1136/bmjopen2018-025729).

Received 30 July 2018 Revised 14 February 2019 Accepted 13 March 2019
D) Check for updates

(C) Author(s) (or their employer(s)) 2019. Re-use permitted under CC BY-NC. No commercial re-use. See rights and permissions. Published by BMJ.

Department of Hygiene and Preventive Medicine, School of Medicine, Fukushima Medical University, Fukushima, Japan

Correspondence to

Dr. T Hidaka; thidaka@fmu.ac.jp

\section{ABSTRACT}

Objectives An operations leader (OL) takes an important role in occupational health management for radiation decontamination workers in Japan, and candidates for the position must participate in a training session to acquire the necessary knowledge as required by law. However, it has not been clarified whether the candidates for the $\mathrm{OL}$ position actually possess accurate knowledge regarding occupational health management for such work after the training session. We, therefore, aimed at examining the current occupational health management knowledge among the candidates and investigating factors related to the knowledge, with hypothesis that possession of accurate knowledge is associated with prior experience of having worked in radiation decontamination.

Design A cross-sectional study.

Setting The training sessions held by Fukushima Prefecture Labor Standard Associations in Fukushima, Japan, in 2017.

Participants Eighty male candidates participated in the training sessions.

Outcome The number/proportion of correct answers to the questions regarding occupational health management, such as those on working environment management, control of operations and health management.

Results The proportion of those who possessed accurate knowledge regarding working environment management, control of operations and health management was $68.8 \%$, $55.0 \%$ and $51.2 \%$, respectively. Experience of radiation decontamination work was associated with the possession of inaccurate knowledge regarding working environment management (OR 0.140 (95\% Cl 0.042 to 0.464$)$ ), and the uncertainty of future radiation decontamination work schedules in difficult-to-return zones was associated with the possession of accurate knowledge regarding health management (OR 4.344 (95\% Cl 1.509 to 12.50)).

Conclusions Previous experience in radiation decontamination work may hinder the ability to acquire accurate information regarding working environment management among candidates for an OL position. To promote adequate occupational health management
Strengths and limitations of this study

- This study was designed to gain an insight into occupational health management among radiation decontamination workers, by focusing on the candidates for operations leaders (OLS).

- This study determined whether OL candidates had accurate knowledge regarding occupational health management.

- This study achieved a higher response rate (99.0\%) and effective response rate (83.3\%) than past studies related to radiation decontamination workers.

- The sample size was relatively small, and thus, there might be potential significant associations that could not be clarified in the current study.

for radiation decontamination workers, it is required to establish an effective instructional method for the $\mathrm{OL}$ candidate training sessions with consideration of previous relevant experience.

\section{INTRODUCTION}

After the Fukushima Daiichi Nuclear Power Plant accident in 2011, the Japanese government designated categories for the following three evacuation areas based on radiation dose rates in 2012': 'difficult-to-return zones' with $50 \mathrm{mSv} /$ year or more; 'no-residence zones' with between 20 and $50 \mathrm{mSv}$ /year and 'zones being prepared for lifting the evacuation order' with $20 \mathrm{mSv} /$ year or less. The full-scale radiation decontamination work for the 'difficult-to-return zones' started from the 2017 fiscal year, whereas radiation decontamination work for most places in the "no-residence zones' and 'zones being prepared for lifting the evacuation order' was completed 
by April 2017. ${ }^{1}$ The Japanese government is responsible for rebuilding 'difficult-to-return zones' that could be made habitable in the near future after decontamination, and thus promotion of radiation decontamination work and restoration of infrastructure becomes a major priority. $^{2}$

Exposure to high doses of radiation among radiation decontamination workers in 'difficult-to-return zones' is of concern. To minimise radiation exposure and take safety precautions during such work, an operations leader (OL) is required to take up an important role regarding occupational health management for radiation decontamination workers. ${ }^{3}$ Companies involved in radiation decontamination must appoint a worker who has knowledge and leadership in directing the radiation decontamination related work as an $\mathrm{OL}^{4}{ }^{4}$ and the candidates for the position must participate in a training session with a standardised curriculum required by law to acquire the necessary knowledge and leadership skills. ${ }^{5}$ The training session was for acquisition of three types of knowledge corresponding to three aspects of occupational health management ${ }^{5}$ : working environment management, such as in the handling of radiation detectors; control of operations, such as methods to instruct radiation decontamination workers how to use protective equipment appropriately; and health management, such as first-aid in case of emergency.

The candidates who completed the training session are expected to have the knowledge and leadership skills required by an OL. However, the actual knowledge after the training session has not yet been clarified. Importantly, there are no legal obligations to confirm whether the candidates actually acquired adequate knowledge after the training session. Moreover, there are no studies on the factors associated with the possession of accurate knowledge of occupational health management for radiation decontamination work.

Past studies reported the occupational health management problems among radiation decontamination workers, such as heat illness, which was regarded the most common health problem ${ }^{6} 7$; mental health issues including anxiety over radiation exposure, which was commonly found among workers ${ }^{8}$; and the problem of control of operation as in not using appropriate measures, such as wearing a dust mask, which was often prevalent. ${ }^{9}$ Although these previous studies proposed solutions to the problems, little is known regarding the OL candidates' knowledge of occupational health management and factors related to their knowledge since the subjects of these past studies were comprised of general radiation decontamination workers. To enhance safety during radiation decontamination work, the knowledge required for OL and its related factors should be verified among the candidates after each training session.

The purpose of the present study was to explore the factors associated with the knowledge that the OL candidates acquired after the training session.

We posit the hypothesis as follows: People with radiation decontamination work experience have accurate knowledge of the work. OL candidates with experience of radiation decontamination work have a basic understanding of the management of the work, including working environment management, control of operations and health management.

\section{METHODS}

\section{Setting and participants}

In this cross-sectional study, in total, 103 candidates for OL positions participated in training sessions held by Fukushima Prefecture Labor Standard Associations on either 7th April, 22nd June or 18th August 2017, in Fukushima Prefecture, Japan. Self-administered questionnaires were handed out at the beginning of each training session, which were answered and returned after the session. One hundred and two candidates returned the questionnaires anonymously (96 males, 4 females and 2 blanks). Because nearly all respondents were male, we included 80 males who completed the questionnaire in the final analysis as the subjects of the present study. The response rate was $99.0 \%$, and the effective response rate was $83.3 \%(80 / 96)$.

From ethical viewpoint, the subjects were explained the purpose of this study verbally and in writing prior to the response to the questionnaires. The explanation consisted of the study purpose, data management policy and voluntary participation to the study.

\section{Measurements}

The variables of knowledge required as an OL and five factors related to the knowledge were measured using questionnaires.

\section{Knowledge required as an $\mathrm{OL}$}

Knowledge required by an OL was classified into three types according to aspects of occupational health management, such as working environment management, control of operation and health management. The knowledge was assessed by the following questions (online supplement): 'Choose one incorrect explanation regarding the measurement of ambient dose rate at decontamination sites in the preliminary survey' for working environment management; 'Choose one incorrect explanation regarding the appropriate use of protective equipment' for control of operation and 'Choose one incorrect method of prevention of heat illness' for health management. These questions were constructed from the law 'Ordinance on Prevention of Ionizing Radiation Hazards at Works to Decontaminate Soil and Waste Contaminated by Radioactive Materials Resulting from the Great East Japan Earthquake and Related Works', ${ }^{4}$ the Guidelines on Prevention of Radiation Hazards for Workers Engaged in Decontamination Works ${ }^{5}$ and a standard textbook used in the training session for the OL candidates. ${ }^{10}$ Total number of correct answers to the knowledge regarding working environment management, control of operation 
Table 1 Characteristics of the subjects

\begin{tabular}{|c|c|}
\hline Age $\pm S D$ (years) & $48.0 \pm 12.4$ \\
\hline$<30$ & $7(8.8)$ \\
\hline 30-39 & $13(16.3)$ \\
\hline $40-49$ & $17(21.3)$ \\
\hline $50-59$ & $27(33.8)$ \\
\hline$\geq 60$ & $16(20.0)$ \\
\hline \multicolumn{2}{|c|}{ Experience as a radiation decontamination worker* } \\
\hline Yes & $44(55.0)$ \\
\hline No & $36(45.0)$ \\
\hline \multicolumn{2}{|c|}{ Permanent employment status $†$} \\
\hline Yes & $67(83.8)$ \\
\hline No & $13(16.3)$ \\
\hline \multicolumn{2}{|c|}{ Future work schedule in difficult-to-return zones $\ddagger$} \\
\hline Yes & $15(18.8)$ \\
\hline No & $30(37.5)$ \\
\hline Not sure & $35(43.8)$ \\
\hline \multicolumn{2}{|c|}{ Anxiety over radiation exposure§ } \\
\hline Very much & $0(0)$ \\
\hline Somewhat & $36(45.0)$ \\
\hline A little bit & $34(42.5)$ \\
\hline None & $10(12.5)$ \\
\hline \multicolumn{2}{|c|}{ Knowledge of working environment management } \\
\hline Have & $55(68.8)$ \\
\hline Do not have & 25 (31.3) \\
\hline \multicolumn{2}{|c|}{ Knowledge of control of operations } \\
\hline Have & $44(55.0)$ \\
\hline Do not have & $36(45.0)$ \\
\hline \multicolumn{2}{|c|}{ Knowledge of health management } \\
\hline Have & $41(51.2)$ \\
\hline Do not have & 39 (48.8) \\
\hline \multicolumn{2}{|l|}{ Summary scoreף } \\
\hline Three & $15(18.8)$ \\
\hline Other & 65 (81.2) \\
\hline
\end{tabular}

${ }^{*}$ Do you have prior experience working in radiation decontamination work?

†Are you currently employed on a permanent basis by your company?

$\ddagger$ Do you have future radiation decontamination work schedule in difficult-to-return zones?

§How much anxiety do you have over radiation exposure? qNumber of correct answers of the knowledge regarding working environment management, control of operation and health management.

and health management was calculated and used as a summary score.

Five factors related to the knowledge

Previous experience in radiation decontamination work, employment on a permanent basis and future radiation decontamination work schedule in difficult-to-return zones were assessed by the following questions: 'Do you have prior experience working in radiation decontamination work?' ('yes' or 'no'); 'Are you currently employed on a permanent basis by your company?' ('yes' or 'no') and 'Do you have future radiation decontamination work schedule in difficult-to-return zones?' ('yes', 'no' or 'not sure').

The degree of anxiety over radiation exposure was assessed using the following question from a past study ${ }^{8}$ : 'How much anxiety do you have over radiation exposure?' The answers were measured on a 4-point scale ( $1=$ 'very much', 2='somewhat', 3='a little bit' and 4='none').

As the sociodemographic data, participant ages were asked and classified into five groups: $<30,30-39,40-49$, $50-59$ and $\geq 60$ years.

\section{Statistical analysis}

Statistical analyses were performed using SPSS statistics V.24. Subjects' characteristics were summarised using descriptive statistics. To have more cases for the analysis, age and degree of anxiety over radiation exposure were classified into two groups: $<50$ or $\geq 50$ and somewhat or a little bit+none, respectively. The associations of the above-mentioned three types of knowledge required for OL with five factors related to the knowledge and summary score were examined by a $\chi^{2}$ test, and then the statistical significance of cells in the tables was analysed using residual analysis. The cells were considered to have significantly more people than expected when the adjusted standardised residual values were greater than 1.96 , whereas the cells were considered to have significantly fewer people than expected when the values were lower than -1.96 .

We stratified the subjects for each type of knowledge required for OL, and then used a binary logistic regression analysis to examine which factor was associated with the possession of accurate knowledge. The independent variables consisted of the five factors, such as age, previous experience in radiation decontamination work (yes), permanent employment status (yes), future work schedule in difficult-to-return zones ('no' was assigned as referent) and anxiety over radiation exposure (somewhat). The models were built-up in two phases. First, all statistically significant variables in $\chi^{2}$ test were included in a model, and then logistic regression was performed by direct method, whereby those factors losing their significance were dropped. Previous experience in radiation decontamination work was included in all models regardless of its statistical significance to verify our hypothesis. The final model was determined based on the result of variable selection: a crude model in the case where no significant variable was observed, an age-adjusted model in the case where the previous experience in radiation decontamination work was the only statistically significant variable, and a multivariate-adjusted model in the case where there was a statistically significant variable other than age and previous experience in radiation decontamination work in the age-adjusted model. 
Table 2 Associations of the five factors with the knowledge regarding working environment management, control of operation and health management

\begin{tabular}{|c|c|c|c|c|c|c|c|c|c|}
\hline & \multicolumn{3}{|c|}{$\begin{array}{l}\text { Knowledge regarding working } \\
\text { environment management }\end{array}$} & \multicolumn{3}{|c|}{$\begin{array}{l}\text { Knowledge regarding control of } \\
\text { operation }\end{array}$} & \multicolumn{3}{|c|}{$\begin{array}{l}\text { Knowledge regarding health } \\
\text { management }\end{array}$} \\
\hline & Have & $\begin{array}{l}\text { Do not } \\
\text { have }\end{array}$ & $P$ value & Have & $\begin{array}{l}\text { Do not } \\
\text { have }\end{array}$ & $P$ value & Have & $\begin{array}{l}\text { Do not } \\
\text { have }\end{array}$ & $P$ value \\
\hline Age (years) & & & 0.096 & & & 0.77 & & & 0.987 \\
\hline$<50$ & $22(59.5)$ & $15(40.5)$ & & $21(56.8)$ & $16(43.2)$ & & $19(51.4)$ & $18(48.6)$ & \\
\hline$\geq 50$ & $33(76.7)$ & $10(23.3)$ & & $23(53.5)$ & $20(46.5)$ & & $22(51.2)$ & $21(48.8)$ & \\
\hline \multicolumn{3}{|c|}{$\begin{array}{l}\text { Experience as a radiation decontamination } \\
\text { worker* }\end{array}$} & $<0.001 \dagger$ & & & 0.718 & & & 0.514 \\
\hline Yes & 23 (52.3)‡ & $21(47.7) \S$ & & $25(56.8)$ & $19(43.2)$ & & $24(54.5)$ & $20(45.5)$ & \\
\hline No & $32(88.9) \S$ & 4 (11.1)‡ & & 19 (52.8) & $17(47.2)$ & & $17(47.2)$ & $19(52.8)$ & \\
\hline \multicolumn{3}{|c|}{ Permanent employment status } & $0.326^{\star *}$ & & & 0.484 & & & 0.838 \\
\hline Yes & $48(71.6)$ & $19(28.4)$ & & $38(56.7)$ & 29 (43.3) & & $34(50.7)$ & $33(49.3)$ & \\
\hline No & $7(53.8)$ & $6(46.2)$ & & $6(46.2)$ & $7(53.8)$ & & $7(53.8)$ & $6(46.2)$ & \\
\hline \multicolumn{3}{|c|}{$\begin{array}{l}\text { Future work schedule in difficult-to-return } \\
\text { zonest† }\end{array}$} & 0.218 & & & 0.908 & & & $0.012 \dagger$ \\
\hline Yes & $10(66.7)$ & $5(33.3)$ & & $9(60.0)$ & $6(40.0)$ & & $9(60.0)$ & $6(40.0)$ & \\
\hline No & $24(80.0)$ & $6(20.0)$ & & $16(53.3)$ & $14(46.7)$ & & $9(30.0) \ddagger$ & $21(70.0) \S$ & \\
\hline Not sure & $21(60.0)$ & $14(40.0)$ & & $19(54.3)$ & $16(45.7)$ & & $23(65.7) \S$ & $12(34.3) \ddagger$ & \\
\hline \multicolumn{3}{|c|}{ Anxiety over radiation exposure $\ddagger \ddagger \S \S$} & 0.716 & & & 0.588 & & & 0.252 \\
\hline Somewhat & $24(66.7)$ & $12(33.3)$ & & $21(58.3)$ & $15(41.7)$ & & $21(58.3)$ & $24(54.5)$ & \\
\hline A little bit+none & $31(70.5)$ & $13(29.5)$ & & $23(52.3)$ & $21(47.7)$ & & $20(45.5)$ & $15(41.7)$ & \\
\hline
\end{tabular}

*Do you have prior experience working in radiation decontamination work?

†Indicates significant association by $\chi^{2}$ test.

‡Indicates adjusted standardised residual $<-1.96$.

§Indicates adjusted standardised residual $>1.96$.

१Are you currently employed on a permanent basis by your company? ${ }^{\star \star} F i s h e r ' s$ exact probability test.

††Do you have future radiation decontamination work schedule in difficult-to-return zones?

¥¥How much anxiety do you have over radiation exposure?

$\S \S$ The category 'very much' was omitted since no subjects fell into this category.

The variance inflation factor (VIF) was used to test multicollinearity for model 3. For health management, the VIF values for age, previous experience in radiation decontamination work and future work schedule in difficult-to-return zones were 1.027, 1.010 and 1.023, respectively. None of the VIF values reached 10 and the mean VIF of the model was less than 6 . Thus, there was no collinearity.

$P$ values below 0.05 were regarded as statistically significant. The OR and 95\% CI were calculated using the regression analysis.

\section{Patient and public involvement}

The participants were not involved in the research question, outcome measures, design, recruitment and conduct of the study. The study participants will have a benefit from the results of this study since the result will provide the improved education for radiation decontamination worker through the feedback to Fukushima Prefecture Labor Standard Associations, although the results will not be disseminated to study participants directly.

\section{RESULTS}

The characteristics of the subjects are presented in table 1 . The mean age of the subjects was 48.0 years (SD 12.4, range 20-71). The number of subjects with previous experience in radiation decontamination work was $44(55.0 \%)$, and those who answered 'yes', 'no' or 'not sure' to the question regarding future radiation decontamination work schedule in difficult-to-return zones were 15 (18.8\%), 30 (37.5\%) and $35(43.8 \%)$, respectively. The numbers of subjects who answered correctly to the questions regarding the knowledge required for OL, such as working environment management, control of operations and health management were $55(68.8 \%), 44(55.0 \%)$ and $41(51.2 \%)$, respectively. The number of subjects who answered correctly to all three questions was $15(18.8 \%)$.

The associations of the five factors with possession of accurate knowledge regarding working environment management, control of operation and health management are indicated in table 2. For working environment management, there was a significant association with previous experience 


\begin{tabular}{|c|c|c|c|}
\hline & \multicolumn{3}{|c|}{ Summary score* } \\
\hline & Three & Other & P value \\
\hline \multicolumn{3}{|l|}{ Age (years) } & 0.266 \\
\hline$<50$ & $5(13.5)$ & $32(86.5)$ & \\
\hline$\geq 50$ & $10(23.3)$ & $33(76.7)$ & \\
\hline \multicolumn{3}{|c|}{$\begin{array}{l}\text { Experience as a radiation decontamination } \\
\text { worker† }\end{array}$} & 0.195 \\
\hline Yes & $6(13.6)$ & $38(86.4)$ & \\
\hline No & $9(25.0)$ & $27(75.0)$ & \\
\hline \multicolumn{3}{|c|}{ Permanent employment status $\ddagger$} & 0.702 \\
\hline Yes & $12(17.9)$ & $55(82.1)$ & \\
\hline No & $3(23.1)$ & $10(76.9)$ & \\
\hline \multicolumn{3}{|c|}{ Future work schedule in difficult-to-return zones§ } & 0.267 \\
\hline Yes & $3(20.0)$ & $12(80.0)$ & \\
\hline No & $3(10.0)$ & $27(90.0)$ & \\
\hline Not sure & $9(25.7)$ & $26(74.3)$ & \\
\hline \multicolumn{3}{|c|}{ Anxiety over radiation exposure $\|^{\star *}$} & 0.886 \\
\hline Somewhat & $7(19.4)$ & $29(80.6)$ & \\
\hline A little bit+none & 8 (18.2) & $36(81.8)$ & \\
\hline
\end{tabular}

*Number of correct answers of the knowledge regarding working environment management, control of operation and health management.

†Do you have prior experience working in radiation decontamination work?

$\ddagger$ Are you currently employed on a permanent basis by your company?

$\S$ Do you have future radiation decontamination work schedule in difficult-to-return zones?

ПHow much anxiety do you have over radiation exposure?

**The category 'very much' was omitted since no subjects fell into this category.

in radiation decontamination work $(\mathrm{p}<0.001)$. For control of operation, no significant associations were observed. For health management, there was a significant association with future radiation decontamination work schedule in difficult-to-return zones $(\mathrm{p}=0.012)$.

The associations of the five factors with summary score are indicated in table 3. No significant associations were observed.

The results of the binary regression analysis are indicated in table 4 . The ORs of knowledge regarding working environment management was significantly lower than 1.000 if the subjects had prior experience in decontamination work both in model 1 and 2 (OR 0.137 (95\% CI 0.041 to 0.453 ) and 0.140 (95\% CI 0.042 to 0.464$)$, respectively). For knowledge regarding control of operations, there were no significant associations. The ORs of knowledge regarding health management was significantly higher than the referent when the subject is uncertain of future radiation decontamination work schedule in difficult-to-return zones consistently in model 1-3 (OR 4.472 (95\% CI 1.569 to 12.74), 4.382 (95\%
CI 1.525 to 12.59 ) and 4.344 (95\% CI 1.509 to 12.50 ), respectively). For summary score, no significant associations were observed.

\section{DISCUSSION}

In the present study, we examined whether OL candidates possessed (or acquired) the accurate knowledge required after the training session and investigated its association with factors related to the knowledge. Contrary to our expectation, our study revealed that previous experience in radiation decontamination work was not associated with the possession of accurate knowledge regardless of which of the three types. Instead, prior experience was associated with inaccurate knowledge of working environment management. Furthermore, accurate knowledge regarding health management was associated with the uncertainty of future radiation decontamination work schedule in difficult-to-return zones.

The result of descriptive statistics suggests that some candidates for the OL position may be in a precarious employment situation. Previous studies reported that Japanese male workers in a precarious employment situation were at higher risk than permanent workers for having serious psychological distress ${ }^{11} 12$ and poor general health, ${ }^{13}$ and for being absent from annual health check-ups. ${ }^{14}$ It is assumed that the candidates with precarious employment may in future be incapable to work due to health problems should they be appointed as OL.

Regarding the anxiety over radiation exposure, there were no subjects who answered 'very much'. Our previous study that was conducted in 2013, measured anxiety over radiation exposure using an equivalent method to the present study, and indicated that the proportion of subjects who had high anxiety was approximately $10 \% .{ }^{8}$ In light of the results of the previous and current studies, the strong anxiety over radiation exposure among radiation decontamination workers may reduce with time.

The number of subjects who correctly answered the questions regarding health management, such as prevention of heat illness, was the lowest among the questions on the knowledge required for the OL. Because heat illness is one of the most common problems among radiation decontamination workers, ${ }^{67}$ this is considered to be a serious issue.

The $\chi^{2}$ tests indicated that there were significant associations of knowledge regarding working environment management with previous experience in radiation decontamination work, and regarding health management with future radiation decontamination work schedule in difficult-to-return zones. Moreover, no significant associations were observed between summary score and the five factors. These facts suggested that the questions for evaluating the knowledge possession were constructed adequately, and that the factors effect on the possession of the knowledge varies by its type.

The binary logistic regression analysis revealed that inaccurate knowledge regarding working environment management was associated with previous experience in radiation 
Table 4 Binary logistic regression for the factors associated with knowledge required for OLs stratified by type and to summary score

\begin{tabular}{|c|c|c|c|}
\hline \multirow[b]{3}{*}{ Variables } & \multicolumn{2}{|l|}{ ORs $(95 \% \mathrm{Cl})$} & \multirow[b]{2}{*}{$\begin{array}{l}\text { Knowledge regarding } \\
\text { control of operation }\end{array}$} \\
\hline & $\begin{array}{l}\text { Knowledge regarding } \\
\text { working environment } \\
\text { management }\end{array}$ & & \\
\hline & Model 1* & Model 2† & Model 1* \\
\hline Age & $1.018(0.980$ to 1.057$)$ & & 0.998 (0.963 to 1.034$)$ \\
\hline $\begin{array}{l}\text { Experience as a radiation } \\
\text { decontamination worker (yes) }\end{array}$ & $0.137(0.041$ to 0.453$) \ddagger$ & $0.140(0.042$ to 0.464$) \ddagger$ & $1.177(0.486$ to 2.854$)$ \\
\hline Permanent employment status (yes) & $0.462(0.137$ to 1.553$)$ & 0.419 (0.121 to 1.447$)$ & $0.654(0.198$ to 2.156$)$ \\
\hline \multicolumn{4}{|c|}{ Future work schedule in difficult-to-return zones } \\
\hline No & Ref & Ref & Ref \\
\hline Yes & 0.500 (0.124 to 2.022$)$ & 0.522 (0.128 to 2.132$)$ & $1.312(0.373$ to 4.616$)$ \\
\hline Not sure & $0.375(0.122$ to 1.151$)$ & $0.393(0.127$ to 1.219$)$ & 1.039 (0.391 to 2.763$)$ \\
\hline $\begin{array}{l}\text { Anxiety over radiation exposure } \\
\text { (somewhat) }\end{array}$ & $0.839(0.325$ to 2.165$)$ & 0.846 (0.326 to 2.196$)$ & 1.278 (0.526 to 3.107$)$ \\
\hline
\end{tabular}

\begin{tabular}{|c|c|c|c|c|}
\hline & \multicolumn{4}{|l|}{ ORs $(95 \% \mathrm{Cl})$} \\
\hline & \multicolumn{3}{|c|}{ Knowledge regarding health management } & \multirow{2}{*}{$\begin{array}{l}\text { Summary score } \\
\text { Model } 1^{*}\end{array}$} \\
\hline & Model 1* & Model 2† & Model $3 \S$ & \\
\hline Age & $0.987(0.952$ to 1.023$)$ & & 0.995 (0.958 to 1.034$)$ & $1.013(0.967$ to 1.061$)$ \\
\hline $\begin{array}{l}\text { Experience as a radiation } \\
\text { decontamination } \\
\text { worker(Yes) }\end{array}$ & 1.341 (0.554 to 3.244$)$ & $1.309(0.538$ to 3.181$)$ & $1.233(0.482$ to 3.156$)$ & 0.474 (0.151 to 1.488$)$ \\
\hline $\begin{array}{l}\text { Permanent employment } \\
\text { status (Yes) }\end{array}$ & $1.132(0.344$ to 3.726$)$ & 1.198 (0.359 to 3.995$)$ & & 1.375 (0.328 to 5.765$)$ \\
\hline \multicolumn{5}{|c|}{ Future work schedule in difficult-to-return zones } \\
\hline No & Ref & Ref & Ref & Ref \\
\hline Yes & $3.500(0.959$ to 12.77$)$ & $3.436(0.936$ to 12.61$)$ & 3.385 (0.919 to 12.46$)$ & 2.250 (0.395 to 12.80$)$ \\
\hline Not sure & $4.472(1.569 \text { to } 12.74)^{*}$ & $4.382(1.525 \text { to } 12.59)^{\star}$ & $4.344(1.509 \text { to } 12.50)^{*}$ & 3.115 (0.758 to 12.80$)$ \\
\hline $\begin{array}{l}\text { Anxiety over radiation } \\
\text { exposure (somewhat) }\end{array}$ & $1.680(0.690$ to 4.089$)$ & 1.676 (0.687 to 4.090$)$ & & $1.086(0.352$ to 3.349$)$ \\
\hline
\end{tabular}

${ }^{*}$ Crude model.

†Adjusted for age (ORs and $95 \% \mathrm{Cl}$ of age were omitted).

łIndicates the statistical significance by logistic regression analysis.

§adjusted for age and experience as a radiation decontamination worker

OLs, operations leaders.

decontamination work. The result suggests that such inaccurate knowledge may be prevalent among radiation decontamination workers. This is supported by previous reports by the Japanese government in that many inadequate cases were reported in terms of working environment management, such as failure to implement the measurement of ambient dose rate at decontamination sites, ${ }^{15-17}$ amounting to 98 cases in total as of 31 March $2017 .^{18}$

There was no significant association between age and knowledge regarding control of operations in the logistic regression analysis. However, it is necessary to focus on the fact that approximately half of the subjects did not have accurate knowledge as shown in the characteristics in table 1 . In this study, knowledge regarding control of operations was assessed by the question on the appropriate use of a dust mask, which is a basic method to prevent internal radiation exposure. $^{19}$

The logistic regression analysis results indicated that the OR of knowledge regarding health management was higher than the referent when the subject was uncertain about future work schedule of radiation decontamination in difficult-to-return zones. There was an association between having accurate knowledge and uncertainty of the schedule among the subjects. Previous psychological studies indicated that uncertainty of the future is associated with a feeling of anxiety, ${ }^{20}$ which is a factor related to motivation. ${ }^{21}$ It is assumed that the learning motivation among the subjects in the current study may have been enhanced by the anxiety derived from uncertainty over future work schedule of radiation decontamination in difficult-to-return zones. 


\section{Limitation}

The sample size of the present study was small. Although our study achieved the effective response rate of $83.3 \%$, which is higher than past studies regarding occupational health management for radiation decontamination workers in Fukushima, ${ }^{82}{ }^{23}$ there might be potential significant associations that could be clarified with a larger sample size. Thus, future studies should recruit a larger sample size. The current study did not include the information of education level of the subjects, in spite of its importance as a potential confounding factor. We considered that the collection of educational information may reduce the response to the questionnaires, because such information is sensitive personal information. Moreover, the knowledge possession should be measured by multiple questions in order to establish more robust evidence.

\section{CONCLUSION}

We revealed that previous experience in radiation decontamination work is associated with inaccurate knowledge regarding working environment management, whereas uncertainty over future work schedule of radiation decontamination in difficult-to-return zones was associated with accurate knowledge regarding health management. To promote adequate occupational health management for radiation decontamination workers, it is required to establish an effective instructional method for OL candidate training sessions with consideration for those with experience of radiation decontamination work.

Acknowledgements We are grateful to Fukushima Prefecture Labor Standard Associations for their assistance with data acquisition.

Contributors TH designed this study, collected and analysed the data, and wrote the manuscript. TKakamu, SE, TS and TKumagai also designed this study and contributed to the analysis. HK, YM, SS and TF critically revised the manuscript. All authors read and approved the final version of the manuscript.

Funding This work was supported by the Fukushima Prefecture Labor Health Center.

\section{Competing interests None declared.}

Patient consent for publication Not required.

Ethics approval This study was approved by the Ethics Committees of Fukushima Medical University (Application No 3035).

Provenance and peer review Not commissioned; externally peer reviewed.

Data sharing statement Extra data can be accessed via the Dryad data repository (http://datadryad.org/withthedoi:10.5061/dryad.jc6h257).

Open access This is an open access article distributed in accordance with the Creative Commons Attribution Non Commercial (CC BY-NC 4.0) license, which permits others to distribute, remix, adapt, build upon this work non-commercially, and license their derivative works on different terms, provided the original work is properly cited, appropriate credit is given, any changes made indicated, and the use is non-commercial. See: http://creativecommons.org/licenses/by-nc/4.0/.

\section{REFERENCES}

1. Fukushima Prefectural Government. Transition of evacuation designated zones. 2018. http://www.pref.fukushima.lg.jp/site/portalenglish/en03-08.html (accessed 24 May 2018).

2. The Asahi Shimbun. First 'hub' set up in Fukushima no-entry zone to speed rebuilding. 2018. http://www.asahi.com/ajw/articles/ AJ201709150058.html (accessed 29 Jun 2018).
3. Ministry of Health, Labour and Welfare of Japan. Leaflet on works under a designated dose rate (for workers). 2012. http://www.mhlw. go.jp/english/topics/2011eq/workers/dr/dr/pr_120615_a08.pdf (accessed 24 May 2018).

4. Ministry of Health, Labour and Welfare of Japan. Ordinance on Prevention of lonizing Radiation Hazards at Works to Decontaminate Soil and Wastes Contaminated by Radioactive Materials Resulting from the Great East Japan Earthquake and Related Works. 2011. http://www.mhlw.go.jp/english/topics/2011eq/workers/ri/rl/rl 130412.pdf (accessed 24 May 2018).

5. Ministry of Health, Labour and Welfare of Japan. Guidelines on Prevention of Radiation Hazards for Workers Engaged in Decontamination Works. 2011. http://www.mhlw.go.jp/english/ topics/2011eq/workers/ri/gn/gn_141118_a01.pdf (accessed 24 May 2018).

6. Wada K, Yoshikawa T, Hayashi T, et al. Emergency response technical work at Fukushima Dai-ichi nuclear power plant: occupational health challenges posed by the nuclear disaster. Occup Environ Med 2012;69:599-602.

7. Tsuji M, Kakamu T, Hayakawa T, et al. [Worker heat disorders at the Fukushima Daiichi nuclear power plant]. Sangyo Eiseigaku Zasshi 2013;55:53-8.

8. Hidaka T, Kakamu T, Hayakawa T, et al. Effect of age and social connection on perceived anxiety over radiation exposure among decontamination workers in Fukushima Prefecture, Japan. J Occup Health 2016;58:186-95.

9. Tsubokura M, Nihei M, Sato K, et al. Measurement of internal radiation exposure among decontamination workers in villages near the crippled Fukushima Daiichi Nuclear Power Plant. Health Phys 2013;105:379-81.

10. Japan Industrial Safety and Health Association. Textbook for operation leaders of decontamination-related work. 4th edn. Tokyo: Japan Industrial Safety \& Health Association, 2015.

11. Kachi Y, Otsuka T, Kawada T. Precarious employment and the risk of serious psychological distress: a population-based cohort study in Japan. Scand J Work Environ Health 2014;40:465-72.

12. Tsurugano S, Inoue M, Yano E. Precarious employment and health: analysis of the Comprehensive National Survey in Japan. Ind Health 2012;50:223-35.

13. Wada K, Higuchi Y, Smith DR. Socioeconomic status and selfreported health among middle-aged Japanese men: results from a nationwide longitudinal study. BMJ Open 2015;5:e008178.

14. Inoue M, Tsurugano S, Nishikitani M, et al. Full-time workers with precarious employment face lower protection for receiving annual health check-ups. Am J Ind Med 2012;55:884-92.

15. Ministry of Health, Labour and Welfare of Japan. Results of supervision/instructions to employers of decontamination works (January-June, 2013) and request to the employers. 2013. http:// www.mhlw.go.jp/english/topics/2011eq/workers/dr/dr/pr_130724. html (accessed 28 May 2018).

16. Ministry of Health, Labour and Welfare of Japan. Results of supervision/instructions to employers of decontamination works. 2014. http://www.mhlw.go.jp/english/topics/2011eq/workers/dr/dr/ pr_140312.html.

17. Ministry of Health, Labour and Welfare of Japan. Results of Supervision/Instructions to Employers of Decontamination Works (January - June 2014). 2014. http://www.mhlw.go.jp/english/ topics/2011eq/workers/dr/dr/pr_140807.html (accessed 28 May 2018).

18. Ministry of Health, Labour and Welfare of Japan. Summary of reporting and responding to inadequate radiation decontamination work (In Japanese). 2017. http://josen.env.go.jp/tekiseika/report_ summary.html (accessed 28 May 2018).

19. Ministry of Health, Labour and Welfare of Japan. Pamphlet on decontamination works (for workers). 2012. http://www.mhlw.go.jp/ english/topics/2011eq/workers/dr/dr/pr_120615_a06.pdf (accessed 28 May 2018).

20. Grupe DW, Nitschke JB. Uncertainty and anticipation in anxiety: an integrated neurobiological and psychological perspective. Nat Rev Neurosci 2013;14:488-501.

21. Ryan RM, Deci EL. Self-determination theory and the facilitation of intrinsic motivation, social development, and well-being. Am Psychol 2000;55:68-78.

22. Kakamu T, Hidaka T, Hayakawa T, et al. Risk and preventive factors for heat illness in radiation decontamination workers after the Fukushima Daiichi Nuclear Power Plant accident. J Occup Health 2015;57:331-8.

23. Endo S, Kakamu T, Sato S, et al. Preventive measures and lifestyle habits against exertional heat illness in radiation decontamination workers. J Occup Health 2017;59:428-32. 